\title{
POST-SOVIET REVOLUTIONS AND POST- REVOLUTION DISCOURSES: EXPLAINING THE CONSTRUCTION OF POLITICAL IDENTITIES IN POST-ROSE REVOLUTION GEORGIA AND POST- VELVET REVOLUTION ARMENIA
}

\author{
Aram Terzyan $^{1}$
}

\begin{abstract}
The 2018 "Velvet Revolution" in Armenia has renewed scholarly interest in post-Soviet revolution studies. This paper explores the core narratives underlying post-Rose Revolution and post-Velvet Revolution identity construction in Georgian and Armenian political discourses. More specifically, it examines the core narratives employed by the Georgian and Armenian revolution leaders Mikheil Saakashvili and Nikol Pashinyan in constructing the political identities of "New Georgia" and "New Armenia." The findings suggest that the core narratives dominating Saakashvili's discourse on post-revolution Georgia are as follows: "democratic Georgia" and "laboratory of democratic reforms," "stereotype breaker," "European Georgia," "peaceful Georgia," "powerful Georgia" and "security contributor," determined to homecoming to Europe. Pashinyan's discourse has revolved around the notion of "proud Armenians," who established "people's government" capable of carrying out an "economic revolution." In contrast to Saakashvili's emphasis on escaping post-Soviet geopolitical space and gaining centrality in the EU-driven socio-political order, Pashinyan's discourse does not suggest foreign policy U-turns. It concludes that while the 2003 "Rose Revolution" marked fundamental shifts in self-other conceptions within the Georgian political discourse, the post-revolution Armenian discourse has not experienced dramatic identity-driven transformations.
\end{abstract}

KEY WORDS: Georgia, Armenia, "Rose Revolution", "Velvet Revolution", PostRevolution discourse.

\section{INTRODUCTION}

The 2018 "Velvet Revolution" in Armenia has renewed a scholarly interest in post-Soviet revolution studies. Before the Armenian revolution, a series of popular protests, which later became known as "color revolutions,"

\footnotetext{
${ }^{1}$ Faculty of Culture and Society, Malmö University, Niagara, Nordenskiöldsgatan 1, Malmö, Sweden, Email: aramterzyan@gmail.com.
} 
had led to non-violent toppling of the incumbent authoritarian or/and semi-authoritarian regimes in Georgia, Kyrgyzstan and Ukraine from 2003 to 2005. There is a lot of scholarship on the political and socioeconomic rationale behind post-Soviet revolutions, that would trace their causes to a series of factors, ranging from electoral fraud to mounting social-economic discontent (Tucker, 2007; Beacháin, Polese, 2010).

There has been a tendency in existing studies to focus specifically on the "anti-Post Soviet" of revolutions, positing that "color revolutions" in Ukraine, Georgia and Kyrgyzstan sought to purge the Newly Independent States' ruling elites and political-economic systems of residual 'Sovietism' (Nikitin, 2007).

While the political and economic causes and effects of the revolutions have been thoroughly studied, the ideational rationale behind postrevolution state-building trajectories have been largely overlooked. In an effort to rectify these shortcomings, some students of the Georgian politics have begun to pay considerable attention to the role of identity, norms and beliefs in Georgia's foreign policy behavior, contending that the latter's pro-Western orientation stems from ideas and identity rather than from materialist and systemic factors alone (Kakachia, Minesashvili, 2015).

Meanwhile, the students of the Armenian politics have been consistent in terms of their "materialist" explanations of the 2018 "Velvet Revolution" and its aftermath. While striving to assess the new government's ability to deliver its economic and political promises, there has been little to no attention to the ideational implications of the revolution (Grigoryan, 2019; Terzyan, 2019a; Markarov, 2018).

This study represents an attemptto fill thevoid, by examining theideational landscape of post-revolution nation-building in Georgia and Armenia. It examines the core narratives employed by the Georgian and Armenian key agents - the President Mikheil Saakashvili and Prime Minister Nikol Pashinyan, in constructing new - post-revolution identities. By analyzing the representation of self and other in Georgian and Armenian discourses, it delves into their ideational connotations and policy implications.

Therefore, the research question is as follows: what are the core narratives underlying post-revolution political identity construction in Georgia and Armenia? It specifically focuses on Georgian and Armenian revolution leaders' discourses on self, friends and foes, as well as those on identity-driven paths and development strategies.

The case study of two neighboring countries aims to contribute to a better understanding of identity politics in post-Soviet, post-revolution societies. 
Over the last decade, the international relations field witnessed a surge in literature dealing with the concept of identity. There has been a tendency to treat identity as if it were an attribute of an institution, being it a state or the European Union, rather than as a defining element of a group of people (Lucarelli, 2008, p. 23). This study builds on constructivist scholarship, to account for "deeply burdened and highly ambiguous" term of identity and its construction (Brubaker, Cooper, 2000). It follows John Gerard Ruggie in accepting that "constructivism is about human consciousness and its role in human life" (Ruggie, 1998, p. 856). Broadly speaking, constructivism is an approach to social analysis based on the following basic assumptions: (a) human interaction is primarily shaped by ideational factors, rather than by material ones; (b) the most significant ideational factors in this context are "intersubjective" beliefs as shared collective understanding; and (c) these beliefs construct the actors' identities and interests (Jung, 2019, p. 2).

Elites are viewed as the key agents in constructing new identities, leading to the demarcation between the self and other (Stråth, 2008, p. 21). Political elites compete with one another to have their preferred national self-image become the national identity and define the state's interests (Clunan, 2009, p. 14). In doing so, they seek to enhance national self-esteem, which entails using value rationality to uphold or create a legitimate social order that institutionalizes values, norms, beliefs, and procedures that give them a positive self-image of their country (Clunan, 2009, p. 14). It follows that foreign policy discourse is not only an expression of collective identity; It is also a process of constructing and reconstructing the self and the other, as well as identifying respective levels of difference and danger from others (Minesashvili, 2016, pp. 11-12). The alterity is of crucial relevance, given that communities usually construct their own identity by imagining themselves in opposition to a significant 'Other' (Tieanu, 2013). In other words, identities are socially constructed and inherently relational, such that collective imagination depends on a dialectical opposition to another identity. The ontology of otherness becomes the necessary basis of social imagination (Göl, 2005). Chaturvedi (2002) even argues that the reflexivity in the process of othering is evident in the character, as well as behavior of nations, which not only define themselves in respect to each other, but also seek for some kind of purity for the self through the demonization of the other (Chaturvedi, 2002).

Nevertheless, this study departs from mainstream treatment of othering as a critical component of identity construction. While the enemy images are viewed as a crucial criteria for defining the self, as well as securing 
the national boundaries by the representation of danger (Campbell, 1998, p. 11), a closer look at the Armenian case prompts a rethink of these assertions. Despite the volatile geopolitics of withstanding blockades unilaterally imposed by Turkey and Azerbaijan (Ghaplanyan, 2017, p. 5), the post-revolution Armenian leadership has not tended to appeal to enemy images to uphold the "borderlines" of self (Petersson, 2006, p. 31) or to divert attention from complex and pressing internal problems. Overall, othering has not been a crucial part of post-revolution identity construction in Armenia.

The study relies on critical discourse analysis to explore what narratives Armenian and Georgian leaders use to construct the post-revolution identities of Armenia and Georgia. It draws on the "ability of narratives to provide a resource for the display of self and identity" (Schiffrin, 1996). Thus, narrative analysis is deemed amenable to examining the issues of identity construction and self-exploration (Crossley, 2007). Bamberg, Fina and Schiffrin (2011) distinguish three dimensions of identity construction that merit emphasis in the discursive construction of identity: (a) the navigation of agency in terms of a person-to-world versus a world-to-person directionality; (b) the differentiation between self and other as a way to navigate between uniqueness and a communal sense of belonging and being the same as others; and (c) the navigation of sameness and change across one's biography or parts thereof (Bamberg, Fina, Schiffrin, 2011). Building on this approach, this study explores the discursive construction of Georgian and Armenian political identities in Georgia's President Saakashvili's and Armenia's Prime Minister Pashinyan's discourses. It juxtaposes Saakashvili's discourse on "New Georgia" with that of Pashinyan on "New Armenia," revealing the divergent patterns of self-definition. Notably, while Saakashvili's discourse would revolve around its Europeanness and homecoming to Europe, Pashinyan has tended to focus more on domestic transformations, centering on the notions of "people's government" and "economic revolution."

The study builds its empirical argumentation by analyzing a broad variety of sources, including the newspaper articles, observations from political speeches, official documents and interviews, which provide a body of discourse. 


\section{THE PORTRAYAL OF "NEW GEORGIA" IN MIKHEIL SAAKASHVILI'S DISCOURSE (2004-2013)}

The 2003 "Rose Revolution" in Georgia ushered Mikheil Saakashvili into power, who came to govern a nation 'cracked open by three breakaway regions, racked by corruption and a tsunami of crime, reeling from two civil wars, pocked by constant electricity and water shortages and unable to collect taxes from its citizens ...'(Greenberg, 2004).

Sahakashvili denounced the plight of declining Georgia on all sides, committing his government to overturning the fundamental basis of the country. He depicted Georgia as a failed state that was "disintegrated, demoralized and humiliated. It was a country that had lost all attributes of statehood; a country where corruption, lawlessness and injustice reigned supreme; a country where ordinary citizens were routinely cheated by the state..." (Saakashvili, 2005a).

No wonder he hailed the "Rose Revolution" as a 'mental revolution', which would herald Georgia's shift from a failed post-soviet state to a European democracy (Jones, 2014, p. 320).

Saakashvili used the following narratives to construct the post-revolution Georgia's political identity:

- "European Georgia" - as the EU's model neighbor, which seeks to become a European center and a hub for the region 'in respect of trade, reforms, development, visual aspects and purely quality matters' (Saakashvili, 2011a). In Saakashvili-led discourse_Georgia's rapprochement with the European Union and NATO was largely framed as an identity-driven foreign policy path and as a civilizational choice: "European and Georgian civilizations are so intertwined that it's difficult to determine whether Europe is Georgia's roots or on the contrary" (Saakashvili, 2008a).

No wonder Saakashvili asserted that "Europe above all - this is the main slogan of our foreign policy and it is the main landmark" (Saakashvili, 2007a). Studies show that Georgia's devotion to the idea of Euro-Atlantic integration as a "sacred destiny" amongst the country's elite has had significant foreign policy implications (Kakachia, Minesashvili, 2015). Notably, Saakashvili would invariably emphasize Black Sea rather than Caucasian dimension of Georgia's political identity, stating that Georgia is a Black Sea European nation, with a political system that is very similar to countries like Romania and Bulgaria (Saakashvili, 2010a). Clearly, in terms of its geographic location and broader cultural identity, Georgia 
is a typical Caucasian country. Nevertheless, Saakashvili consistently strived to reframe Georgia as a Black Sea country, in line with Bulgaria and Romania. Presumably, the latter's' success stories of EU and NATO memberships led Saakashvili to the conclusion, that Georgia would gain better acceptance by the Euro-Atlantic community as a Black Sea country. Put simply, given that the Black Sea is an inseparable part of Euro-Atlantic security system, Georgia's membership of the Black Sea community would make it inherently European (Minesashvili, 2016, p. 26). Therefore, the Georgian discourse would distance the country from a conflict-prone and 'backward' Caucasus region- largely viewed as a 'sphere of Russian influence'.

- "Democratic Georgia" and "laboratory of democratic reforms" in the post-soviet space, which would serve as a living example of how governing transparently, through democratic principles, breeds lasting stability and shared prosperity (Saakashvili, 2010b, Saakashvili, 2007b). Saakashvili's discourse suggests that democracy promotion would be pivotal to boosting partnerships with Georgia's most desired partners - European Union and NATO. Therefore, consistent and fundamental democratic reforms would enable Georgia to knock at the door of its natural home - the European Union (Saakashvili, 2012a). Saakashvili invariably stressed the necessity of big steps and groundbreaking reforms, given that Georgia was in no position to slow down, and there was no alternative to fundamental reforms: "either we will be successful or Georgia will not exist any longer" (Saakashvili, 2010c). Furthermore, he hailed democracy as a buffer against hostilities towards Georgia "Democracy defends our country and destroys our enemy" (Saakashvili, 2008b).

Therefore, democracy promotion, rather than military build-up would be key to addressing foreign policy threats posed to Georgia chiefly by its belligerent neighbor Russia. Most importantly, democracy and prosperity would equip Georgia with 'soft' tools for reintegrating separatist regions Abkhazia and South Ossetia into a common Georgian state. 'When we talk about what democracy means, it is a chance for Georgia to solve its problems, problems with our neighbors, problems associated with our conflicts' (Saakashvili, 2005b). Democratic and peaceful Georgia would respond to military build-ups with programs to lift children out of poverty through access to modern technologies, with new hotels and new bicycling roads, new boulevards (Civil Georgia 2011). Furthermore, peaceful 
Georgia "will never use force to restore its territorial integrity and sovereignty" (Georgia Journal, 2010).

- "Stereotype breaker Georgia" as its "success destroys the myth that corruption is cultural and gives hope to reformers everywhere who aspire to clean up their public services" (Saakashvili, 2012b). Saakashvili's Georgia had a special mission of conveying the idea of Georgia's freedom - spread it in all of the post-Soviet space (Saakashvili, 2011b).

Saakashvili's discourse suggests that the 'mental revolution 'made Georgia a role model for post-soviet countries. More specifically, it served as an ardent catalyst for the "Orange Revolution" in Ukraine and "Tulip Revolution" in Kyrgyzstan.' Furthermore, Saakashvili regarded the "Rose Revolution" as 'the second wave of Europe's liberation, the first one being the velvet revolutions in Prague and Warsaw' (Saakashvili, 2005c). Overall, Georgia has been portrayed as a front-runner in the region, which should be a model for neighboring countries (Minesashvili, 2016, p. 19).

- "Powerful Georgia." Saakashvili vehemently questioned the notion of 'tiny Georgia', noting that the weight of a state should not be measured by the size of its territory or military capabilities. Rather, it is measured by its culture, the quality of democracy, and ability to undergo fundamental reforms. "In terms of land area, Georgia is twice the size of the Netherlands and bigger than Slovakia, but I have never read or heard of anyone referring to these countries as "tiny Netherlands" or "tiny Slovakia". I have never even heard "tiny Luxembourg", even though that country is about as big as central Tbilisi. These are the clichés that are gradually falling by the wayside" (Saakashvili, 2007c).

Therefore, his discourse suggests that Georgia is powerful enough to stand up for its sovereignty, reinforce its territorial integrity and would not cede even an inch of its territory (Saakashvili, 2006).Thus, Georgia was portrayed as a powerful country that would no longer carry the stigmas of a weak and puppet state, that would never fall to its knees since as 'It is impossible to defeat Georgia' (Saakashvili, 2007d).

Saakashvili redefined Georgia's international actorness shifting it from a passive recipient to an active player, from a security consumer, to a security contributor, particularly within the NATO. Not surprisingly Georgia deployed 
its armed forces in Afghanistan and undertook considerable measures to redefine its actorness in Euro-Atlantic security community (Saakashvili, 2012b).

Studies show that despite a series of setbacks and shortcomings Saakashvili's rhetorical commitments tended to translate into reality (Aliyev, 2014). This particularly applies to the fight against corruption, poverty reduction, economic growth and overall democratic reforms. All this found its expression in Investment Climate Statement, 2014 of the US Department of State, which underlines Georgia's sweeping economic reforms since the "Rose Revolution," that moved the country from a near-failed state in 2003 to a relatively well-functioning market economy in 2014 (State.gov 2014) .

To sum up, to construct new political identity for post-revolution Georgia, Saakashvili made extensive use of the following narratives: "democratic Georgia" and "laboratory of democratic reforms," "European Georgia," "Peaceful Georgia," "Stereotype breaker," "Powerful Georgia" and "Security contributor." All these narratives were used to distance Georgia from "postSovietism" and prepare ground for its homecoming to Europe, in the form of accession into the European Union and NATO.

\subsection{The Portrayal of "The Other" in Saakashvili's Discourse}

"Rose" or "Mental revolution" significantly influenced the perceptions of friends and foes in Georgian political thinking. From the outset of his presidency, Saakashvili would emphasize the necessity of "departing" from Russian-dominated post-Soviet space and redefining asymmetric i.e. 'patron-client' relations with Russia. Thus, it was absolutely essential for Georgia to build resilience against neighboring inherently imperial and coercive Russia: 'We should have boundless trust that we as a country will never be defeated by [Russia's] 11th army [like in 1921 when Bolshevik Russia occupied Georgia] no matter in what shape it comes here. No alien force will ever be able to make us turn back. We should have boundless trust that all of us together have a common and very bright future. This trust will help us win a victory (Saakashvili, 2007e).

Saakashvili's discourse suggests that "reborn" Georgia would make most out of the partnerships with its strategic allies US, NATO and the EU as a buffer against the Kremlin's imperial ambitions.

Saakashvili's position on Russia hardened as the latter took measures to suppress the emerging democracy in its neighborhood. More specifically, in March 2006 Russia decided to ban all imports of Georgian wine. Besides, 
a series of discriminatory measures were employed against the Georgian population in Russia (Terzyan, 2019b, p. 133-134). The situation came to a head in August 2008, manifested in the eruption of Russian-Georgian war. The Russian simmering aggression towards Georgia brought Saakashvili to the conclusion that "old KGB followers decided to finish the so-called "Georgian project", our common attempt to create a modern, European, democratic, successful state in Caucasus (Terzyan, 2019b, p. 134).

Remarkably, Saakashvili would frequently contrast Georgia's values with those of Russia, pointing to major gaps and differences. More specifically, 'Georgia is a democracy, unlike Russia, which is not a democracy' (Saakashvili, 2008c). He contrasted peaceful Georgia with 'aggressor' Russia, which suffers from imperialistic adventurism and unrealistic illusions of restoring the Russian empire (The Guardian, 2009).

Moreover, he hailed Russian-Georgian conflict as an ideological confrontation, in which the Kremlin abuses its status as a "great power" to coerce "a small and insubordinate neighbor. In one word this is an ideological confrontation. From the subjective perspective of Russia's today's Government - Russia is a "street boy". It's leadership has criminal authority and Georgia all the sudden turned into a "best student" - a boy or a girl, he is getting the best marks, everybody likes, everybody cuddles, everybody want to help, everybody wants to open the way to him. Of course, he is not obeying the rules set by the "street boy". "The street boy" hits him once, second, third time it pushed him with a shoulder, then it cursed him... finally the "street boy" decided to hit him well, but the "best student" slept back his hand and poked "street boy" back... Of course, for the mentality of "street boy" this is absolutely unacceptable situation" (Saakashvili, 2010d).

The five-day war against Georgia prompted Saakashvili to put Russia in the category of Nazi Germany and Stalin's Soviet Union: "This is the first attempt since Nazi Germany and Stalin's Soviet Union, when a large state tried to at first force a neighboring state to kneel down and then tries to openly annex two regions, hence is trying to redraw borders in Europe'(Saakashvili, 2008d).

Essentially, Saakashvili consistently strived to put a Russian-Georgian conflict in the framework of Russia-West/EU confrontation and even asserted that the underlying objective of the Russian aggression was to destroy, occupy and capture Georgian territories as an episode of the European history (Saakashvili, 2008e).

Thus, Europe had a crucial mission of standing up for 'oldest Europeans'. Saakashvili would repeatedly contend that Georgia's accession into EU 
and NATO would produce a geopolitical breakthrough and significantly constrain Russia's mounting assertiveness. 'Our goal - and I have already appealed to all the concerned leaders - is accelerated integration into NATO in order to prevent reoccurrence of past mistakes and Georgia's accelerated integration into European Union. We are part of the democratic world and the democratic world should embrace Georgia' (Civil Georgia, 2008).

Not surprisingly, Saakashvili frequently contrasted Europe with Russia framing it as a confrontation between the rule of law and the rule of fear (Civil Georgia, 2010). The Georgian political elite has consistently fed the "clash of civilizations" narrative asserting that the Russian model will eventually fail as it is not compatible with the modern era (Minesashvili, 2016, p. 22).

To sum up, Saakashvili attributed Russian and Soviet Russia's image to modern Russia and resorted to ideological othering of "imperial', 'KGB-led' and 'coercive' Russia. No wonder, he prescribed the path that would pull the country out of the Russian autocratic influence and lead to its homecoming to the European family of democracies. This vision yielded tangible results in June 2014, when Georgia signed an Association Agreement with the EU, which entered into force on July 1, 2016 (EEAS, 2016).

\section{THE PORTRAYAL OF "NEW ARMENIA" IN NIKOL PASHINYAN'S DISCOURSE: “PEOPLE'S GOVERNMENT" AND “ECONOMIC REVOLUTION" AS THE CORE NARRATIVES}

Post-revolution Armenia's Prime Minister Nikol Pashinyan has inherited a country, fraught with corruption, weak rule of law, lack of economic opportunities and poverty. No wonder, Pashinyan's discourse predating and postdating the "Velvet Revolution" has revolved around the narrative of "New Armenia" - a country of law and justice, prosperity and democracy (Pashinyan, 2019). Therefore, the biggest mission of the new government would be the fight against corruption and other authoritarian malpractices to make sure that "never again will anyone dare to humiliate our people through vote-buying practices, administrative coercion or in any other way", as "any attempt to stop this rebirth and flight of the Armenian people and to strangle their hope and optimism in corruption and permissiveness will meet a crushing counter-attack" (Pashinyan, 2018a).

A closer scrutiny of Pashinyan's discourse suggests that the core characteristic of "New Armenia's" political identity is the "people's government": "before April 2018, Armenia's dominant political factor was 
the criminal, economic, political elite, while the people's will has become the country's dominant political factor after the revolution... Yes, the people's power is established in Armenia; yes, we have a people's government in Armenia" (Pashinyan, 2018b).

A closer look at the discourse on "people's government" shows a blurred line between state and society. Given a huge public support for Pashinyan's government manifested in its landslide parliamentary victory in December 2018, Pashinyan and his proxies would even contend that any step against their government is a step against the Armenian people, as they represent "people's government" (Factor, 2019).

Pashinyan's discourse suggests that he embodies the will of the people and that Parliament's legitimacy is based on that will: "In Armenia, there is no coalition government. In Armenia, there is no parliamentary majority. In Armenia, the ultimate power directly belongs to the people and the people carry out direct rule. This is the key meaning of the revolution that took place in Armenia" (Armenian Weekly, 2018).

Clearly, in attempts of rousing public protests against Sargsyan's regime, Pashinyan would subject former president's government to fierce criticism for its inability to raise living standards and eliminate corruption. Meanwhile, his discourse on post-revolution Armenia's development strategy suggests that government has little to do with those issues, as long as in "people's government"-led Armenia people are the sole source of reforms and changes. The government is "only a partner and should not be seen as a giver of work" (Eurasianet, 2019a).

Notably, in the speech he gave to introduce the program, Pashinyan said that "poverty is in people's minds" (Eurasianet, 2019a). He added that "the numerical parameters of the economic revolution actually depend on how many Armenian citizens will respond to our call to become activists of the economic revolution and how many will decide to take advantage of the opportunities of the same revolutionary platform" (Eurasianet, 2019a). It follows that any possible failure of the new government would be people's failure unable to overcome "poverty in their minds."

Pashinyan would make extensive use of the "people's government's" narrative to stress the necessity of fundamental judicial reforms as "the people of Armenia continue to perceive the judiciary as a leftover of the former corrupt regime that continues to plot and execute deceptions against the people," said Pashinyan, who also called for the resignation of the country's sitting judges and a new vetting process for new judges (Armenian Weekly, 2019). Moreover, he went as far as to accuse Armenia's 
judicial system of conspiring against him and his Government and declared that the next phase of the "Velvet Revolution" will take the form of judicial reform (Kucera, Mejlumyan, 2019).

The confrontation between Pashinyan's government and the "remnants" of the former regime escalated to a point, where the Armenian parliament adopted a bill on holding a referendum on suspending the powers of a majority members of the Constitutional Court.

Pashinyan hailed the current Constitutional Court as an obstruction to completing the revolution in Armenia. Moreover, Pashinyan has treated the Constitutional Court as an instrument that prevented the Armenian people from exercising their right to form a government in the country in the 1996, 1998, 2003, 2008, 2013 presidential elections and thus represents the corrupt regime of Serzh Sargsyan, rather than the people of Armenia (Pashinyan, 2020). These contentions would be followed by the claim that the opponents of the referendum as "anti-state" forces due to their opposition to breaking with "people government"- led Armenia's authoritarian legacy (Eurasianet, 2020). Overall, the narratives of "people's government" and "proud Armenians" have been frequently used to legitimize government's policies and even shield it from unwanted opposition, by framing every 'sabotage' against the government a step against the Armenian people (Factor, 2019).

Arguably, such a discourse would contribute to the development of an "Us" /" Them" binary that involves the semantic strategies of positive Selfpresentation and negative Other - presentation. In Pashmina's speeches, this binary poses "Us", the essentially good and revolutionary protagonists, against "Them", the leftovers of the old regime and counter-revolutionaries who are poised to hinder democratic reforms and exert devastating influence over the country.

In this way, Us/Them polarization is a key legitimation strategy - an argumentative technique that rhetors employ to scapegoat and target the rivals for actual and potential shortcomings and wrongdoing (Oddo, 2011).

Interestingly, Pashinyan has put forth hundred facts about "new Armenia" emphasizing the accomplishments in raising living standards by increasing salaries, promoting economic rejuvenation, increasing military capabilities, fighting against corruption and ensuring judicial independence, as well as promoting homecoming of immigrant Armenians (Pashinyan, 2019b).

Arguably, in contrast to Saakashvili's invariably ambitious discourse on "missionary," European and powerful Georgia, Pashinyan's one has been limited to strictly socio-economic and domestic political issues. That said, 
while Saakashvili would hail the "Rose Revolution" as "mental revolution", there has been a strong tendency for Pashinyan's discourse to revolve around "economic revolution."

"The economic revolution has begun," said Prime Minister Nikol Pashinyan, presenting the program in parliament on February 12, 2019 (Eurasianet, 2019b). "I am announcing the start of the nationwide economic revolution in the Republic of Armenia. The Armenian people won in the fight against corruption, impunity and clan management, and the Armenian people will win in the fight against poverty and unemployment" (Eurasianet, 2019b).

The government plan promises a "significant decrease" of the severe poverty in Armenia and a "significant decrease in unemployment by 2023" (Civilnet, 2019). Very small businesses would be exempt from taxes; public sector salaries would be increased. The plan gave a few specific targets: that GDP would increase by five percent a year, exports would be increased to over 40 percent of GDP by 2024, and solar energy would make up 10 percent of the country's total consumption by 2022 (Civilnet, 2019).

Remarkably, Pashinyan markedly departed from his predecessors strong tendency of citing unfavorable external conditions, ranging from the closed borders with neighboring Azerbaijan and Turkey, to the absence of effective land communication with the rest of the world as the core excuses for economic failures (Abrahamyan, 2019). Rather, he finds the new economic model "with an inclusive economic system meaning that all the citizens of the Republic of Armenia will have equal opportunities, accessibilities, liberties to carry out economic activities and be equal in the eyes of the law and tax services" pivotal to achieving the long-desired "economic revolution" (Pashinyan, 2019b).

Thus, Pashinyan deems an economic turnaround feasible even amid Armenia's full-scale integration into the Russian-dominated Eurasian Economic Union (EAEU) that he would previously hail as an impediment to Armenia's economic development (Aravot, 2017).

It is worth to note that articles 4 and of the treaty on the EAEU obligates member states to create common market of goods, labor and services and have their economic policies complied with the goals and principles of the EAEU (Treaty on the EEU 2014, art. 4, 5). According to article 25, there is a common regime of trade of goods with third parties (Treaty on the EEU 2014, art. 25). All these stipulations suggest that Armenia is considerably constrained to boost trade and broader economic cooperation with the EU. 
It is perhaps for this reason that some observers have greeted Pashinyan's claims of "economic revolution" with skepticism, noting that the scope of economic opportunities and international trade would be inevitably constrained by the EAEU membership (Grigoryan, 2019).

Arguably, well acknowledging the dire constraints stemming from Armenia's Eurasian economic integration, Pashinyan seeks to offset unfavorable external conditions by fostering domestic economic reforms. In essence, the narrative of the "economic revolution" along with Pashinyan's "2050 economic vision" that envisages Armenia's GDP's 15-fold growth by 2050 (Eurasianet, 2019c) seeks to keep the flame of post-revolution enthusiasm and his popularity alight amid possible setbacks and economic hardships.

Clearly, there is no magic bullet for getting the Armenian economy on its feet and the economic recovery has much to do with significant improvements in country's political and legal landscapes leading to the rule of law, judicial independence and accountability of elected officials. Meanwhile, the social and economic discontent of the Armenian population prompted Pahsinyan to place a heightened emphasis on "economic revolution," largely treated as the next stage of the 2018 "Velvet Revolution."

\subsection{No Foreign Policy U-Turns: Same Friends, Same Foes?}

Given former opposition leader Nikol Pashinyan's critical stances on Armenia's plight in Russia-led unions, it would be easy to resort to speculations about possible foreign policy changes and Armenia's advancement towards the EU. Notably, in the fall of 2017 Pashinyan-led "Yelk" parliamentary faction submitted a bill proposing Armenia's withdrawal from the Russia-led Eurasian Economic Union - framed as a dormant union detrimental to country's interests (Terzyan, 2019c, p. 101). Furthermore, Pashinyan would denounce the Russian policy towards Armenia on all sides, stressing particularly the 'cynical interventions in Armenia's domestic affairs. Therefore, "the fear that joining the EAEU will result in serious threats to the sovereignty of Armenia, has become stronger" (Aravot, 2017).

Yet, from the very beginning of his prime ministership Pashinyan fundamentally changed his stances on the EAEU and on the ArmenianRussian partnership.

During the first meeting with the Russian President Pashinyan particularly noted: "We have things to discuss, but there are also things that do not need any discussion. That is the strategic relationship of allies between Armenia and Russia ... I can assure you that in Armenia there is a consensus, and 
nobody has ever doubted the importance of the strategic nature of Armenian Russian relations" (Reuters, 2018). Moreover, he confirmed Armenia's commitment to deepening further integration in the Eurasian Economic Union, framing it as beneficial to the country: "Armenia is eager to see the furtherance of integration processes in the Eurasian Economic Union. We are ready to do our best to further develop the integration-targeted institutions and find new ways and mechanisms for cooperation" (Terzyan, 2019c, pp. 101-102).

The dramatic changes of Pashinyan's discourse suggest that the power transition in Armenia has not led to revising Armenian-Russian relations and reversing Armenia's membership in the Russia-led EAEU.

Furthermore, Pashinyan has invariably stated that Armenia's foreign policy would not undergo U-turns, and therefore, the status of Russia as 'indispensable ally' would remain uncontested. Therefore, Armenia would seek further rapprochement with its 'big brother': "The Republic of Armenia is not going anywhere...and the Armenian-Russian strategic friendship will be deepened and developed ahead...One of our primary objectives is to build on the Armenian-Russian friendship and raise the Armenian-Russian relations to a new level... I promised that the Armenian-Russian relations would be upgraded, and today I want to tell you that after giving it the required formalities, we will inform you about a joint Armenian-Russian humanitarian project, which is unprecedented in the Third Republic's history following the collapse of the Soviet Union. It will come as an unprecedented instrument of partnership and vivid evidence that we are going to consistently upgrade our relations" (Pashinyan, 2018c).

Moreover, in contrast to his initial criticism of Russian "cynical interventions in Armenia's domestic affairs" and their adverse effects on democracy promotion in Armenia, Pashinyan firmly denied the notion of Russian authoritarian diffusion: "...I want to speak about something that used to be the case in Armenia over the past many years. For instance, the authorities often behaved in such a way that many negative domestic phenomena used to be attributed to Russia. Why did this happen? Just because the corrupt authorities wanted to shake off the responsibility for their deeds as if they were not guilty, and there were some external forces prompting them to be corrupt..." (Pashinyan, 2018c).

Essentially, there has been little emphasis on Armenia's Europeanness and European foreign policy aspirations in Pashinyan's-led discourse. In response to a question regarding a Russian-European balance, Pashinyan noted: "I don't think it's right formulation - to have balance as a goal. The most important 
goal of our foreign policy is to make our independence stronger and stronger, to defend our sovereignty and security etc." (Euronews, 2019). Meanwhile, studies show that the emphasis on security smoothly leads to Russia's treatment as indispensable security ally (Aberg, Terzyan, 2018, p. 168).

Essentially, the persistence of troubled relations with neighboring Azerbaijan and Turkey further feeds the narrative that the security alliance with Russia is pivotal to building Armenia's resilience against hostile neighbors.

Clearly, it would be unrealistic to expect major breakthroughs in Armenia's troubled neighborhood following the "Velvet revolution." Moreover, Pashinyan's emphasis on Nagorno Karabakh's inclusion in the negotiations with Azerbaijan, as well as his contention that "Artsakh is Armenia, and that is it" has been met with Azerbaijani leadership's rejection and the assertion that "Nagorno-Karabakh is Azerbaijan" and that "Azerbaijan will restore its territorial integrity. Responsibility for the consequences lies with the Armenian side" (Asbarez, 2019).

Such statements are testaments to persisting hostility between Armenia and Azerbaijan with no considerable sign of de-escalation of thelong-standing confrontation in the aftermath of the "Velvet Revolution." Meanwhile, the lessons of failed Armenian-Turkish rapprochements suggest that there can be no significant development in Armenia-Turkish relations until at least the de-escalation of the Nagorno Karabakh conflict. This assumption is based on Azerbaijan's vast opposition to Armenian-Turkish rapprochement, which proved instrumental in thwarting it (Terzyan, 2018, p. 165). Turkey is well aware of Azerbaijan's approach to the "Armenian issue" and is highly unlikely to take any measure that would upset bilateral strategic ties.

Overall, the perception of the foes as hostile, belligerent and destructive has largely remained unchanged in Armenia's political discourse (Terzyan, 2018). This comes as no surprise, as the structural conditions determining these conceptions have not changed, leaving the double blockade imposed on Armenia intact.

In contrast to Georgian revolution leader, who would regard democracy promotion and Europeanization as a recipe for security, consistent with his predecessors, Pashinyan seems to prioritize the security alliance with Russia as a critical bulwark against difficult neighbors. Not surprisingly, he has regarded the military partnership with Russia as a major factor for Armenia's security (Tass, 2018).

As a result, in contrast to neighboring Georgia's "vocal centrality", the Armenian government has offered a drastically different vision of its role 
in the EU-driven socio -political order by consciously choosing to appear marginal (Delcour, 2019). The comparative analysis of two neighboring countries' positioning vis-à-vis the EU, provides insights into the dominant perceptions of Georgia as a frontrunner aspiring to EU membership and Armenia as a hesitant partner of the EU (Delcour, 2019, p. 15). This comes down to Armenia's continued centrality in the Russia-led socio-political order.

\section{CONCLUSION}

The aim of the article was twofold: (1) To explore the core narratives in post-Rose Revolution Georgia's and post-Velvet Revolution political discourses and (2) To account for divergent patterns of political identity construction in Georgia and Armenia. The findings suggest that while Georgian President Mikheil Saakashvili's discourse on "New Georgia" would revolve around its Europeanness and homecoming to Europe, Pashinyan has tended to focus more on domestic transformations, centering on the notions of "people's government" and "economic revolution." In contrast to Saakashvili's emphasis on escaping post-Soviet geopolitical space and gaining centrality in the EU-driven socio-political order (Kakachia, et. al, 2019; Delcour, 2019), Pashinyan's discourse does not suggest foreign policy U-turns. Instead, "economic revolution" is deemed pivotal to putting "people government"-led Armenia on the path to prosperity, democracy and security.

Overall, the core narratives dominating Saakashvili's discourse on postrevolution Georgia's political identity are as follows: "democratic Georgia" and "laboratory of democratic reforms," "stereotype breaker," "European Georgia," "peaceful Georgia," "powerful Georgia" and "security contributor," determined to become a full-fledged member of the European Union and NATO. Pashinyan's discourse has revolved around the notion of "proud Armenians," who established "people's government" capable of carrying out an "economic revolution." While Saakashvili would hail the "Rose Revolution" as "mental revolution," Pashinyan has tended to pay more attention to the "Velvet Revolution's" transformation into an "economic revolution."

Another divergence between Armenian and Georgian post-revolution discourses that merits emphasis, has to do with the conceptions of friends and foes (the "Other"). The Georgian "mental revolution" prompted Georgia to "depart" from "imperial," "coercive" and "KGB-led" Russia and seek "asylum" in European family of democracies. In essence, the othering of 
Russia became a crucial part in "New Georgia's" identity construction, as Saakashvili tended to regard Russia as European Georgia's clearly identifiable other with an opposing ideology, aimed to "destroy, occupy and capture Georgian territories as an episode of the European history" (Saakashvili, 2008e). Thus, the Russian-Georgian conflict was framed as an ideological confrontation between European Georgia and its ideological rival Russia.

Meanwhile, the "Velvet Revolution" has not extended to Armenia's foreign policy landscape and there have been no major shifts in the conceptions of friends and foes. Consistent with his predecessors' approach, Pashinyan keeps treating the security alliance with 'indispensable ally' Russia as a critical bulwark against neighboring Azerbaijan's and Turkey's hostilities. That said, the Armenian revolution has not led to revise the dominant narratives of friends and foes in Armenian political thinking, as the structural constraints underlying these narratives have remained intact.

Further research could focus on the evolution of the core narratives for post-Velvet Armenia's identity construction and their implications for its domestic and foreign policy.

\section{REFERENCES}

ABERG, J. H., TERZYAN, A. (2018). Structure or agency? Explaining Armenia's foreign policy evolution. In: Eastern Journal of European Studies. Vol. 9, No. 1, 2018, pp. 151-172.

ABRAHAMYAN, P. (2019). Economic revolution or hopes for a miracle. EVN Report. [online]. Available at: <https://www.evnreport.com/economy/ economic-revolution-or-hopes-for-a-miracle>. [Accessed 20th March 2020].

ALIYEV, H. (2014). The effects of the Saakashvili era reform on informal practices in the Republic of Georgia. In: Studies of Transition States and Societies. Vol. 6, No. 1, 2014, pp. 19-33.

ARAVOT (2017). Pashinyan insisted: 'EAEU is a threat to Armenia and is dangerous'. [online]. Available at: <https://www.aravot-en. $\mathrm{am} / 2017 / 09 / 27 / 200463 />$. [Accessed 13th July 2019].

ARMENIAN WEEKLY (2018). Highlights from Pashinyan's first 100 Days Speech. [online]. Available at: <https://armenianweekly. com/2018/08/18/highlights-of-pashinyans-first-100-days-speech/>. [Accessed 12th July 2019].

ARMENIAN WEEKLY (2019). Kocharyan trial suspended in the wake of Pashinyan - court standoff. [online]. Available at: <https:// 
armenianweekly.com/2019/05/22/kocharyan-trial-suspended-in-thewake-of-pashinyan-court-standoff/>. [Accessed 15th July 2019].

ASBAREZ (2019). Baku angry over Pashinyan's 'Artsakh is Armenia' comment. [online]. Available at: <http://asbarez.com/183732/baku-angry-overpashinyans-artsakh-is-armenia-comment/>. [Accessed 14th July 2019].

BAMBERG, M., DE FINA, A., SCHIFFRIN, D. (2011). Discourse and identity construction. In: Handbook of Identity Theory and Research. New York: Springer, 2011, pp. 177-199.

BEACHÁIN, D. Ó., POLESE, A. (eds.). (2010). The color revolutions in the former Soviet republics: successes and failures. Routledge, 2010.

BRUBAKER, R., COOPER, F. (2000). Beyond "identity". In: Theory and society. 29(1), pp. 1-47.

CAMPBELL, D. (1998). Writing security: United States foreign policy and the politics of identity. Minneapolis, MN: University of Minnesota Press, 1998.

CHATURVEDI, S. (2002) Process of othering in the case of India and Pakistan. In: Tijdschrift voor economische en sociale geografie. Vol. 93, No. 2, 2002, pp. 149-159.

CIVIL GEORGIA (2008). Saakashvili address on Russia's Abkhazia, S. Ossetia recognition. [online]. Available at: <http://www.saakashviliarchive. info/en/PressOffice/News/SpeechesAndStatements? $\mathrm{p}=2312 \& \mathrm{i}=1>$. [Accessed 22th July 2019].

CIVIL GEORGIA (2010). Saakashvili's address to European Parliament. [online]. Available at: <http://www.civil.ge/eng/article.php?id=22883>. [Accessed 12th July 2019].

CIVIL GEORGIA (2011). Saakashvili's speech at the UN General Assembly 2011. [online]. Available at: <http://www.civil.ge/eng/article. php?id=23958 $>$. [Accessed 23th July 2019].

CIVILNET (2019). Among people under 30, unemployment rate still high in Armenia. [online]. Available at: <https://www.civilnet.am/ news/2019/04/19/Among-People-Under-30-Unemployment-RateStill-High-in-Armenia/359004>. [Accessed 17th July 2019].

CLUNAN, A. L. (2009). The social construction of Russia's resurgence: Aspirations, identity, and security interests. JHU Press, 2009.

CROSSLEY, M. (2007). Narrative analysis. In: Analyzing Qualitative Data in Psychology. pp. 131-144.

DELCOUR, L. (2019). Armenia's and Georgia's contrasted positioning vis-àvis the EU: between vocal centrality and strategic marginality. In: Journal of Contemporary European Studies. Vol. 27, No. 4, 2019, pp. 1-12. 
EEAS (2016). EU/Georgia Association Agreement. [online]. Available at: <https://eeas.europa.eu/delegations/georgia_en/9740/EU/ Georgia\%20Association\%20Agreement>. [Accessed 18th August 2019]. EURASIANET (2019a). New Armenian government bets on the free market. [online]. Available at: <https://eurasianet.org/new-armeniangovernment-bets-on-the-free-market>. [Accessed 15th July 2019].

EURASIANET (2019b). Armenia adopts plan for "economic revolution." [online]. Available at: <https://eurasianet.org/armenia-adopts-plan-foreconomic-revolution>. [Accessed 16th July 2019].

EURASIANET (2019c). Pashinyan calls for unification between Armenia and Karabakh. [online]. Available at: <https://eurasianet.org/pashinyancalls-for-unification-between-armenia-and-karabakh>. [Accessed 17th July 2019].

EURASIANET (2020). In new bid against court, Pashinyan calls for referendum. [online]. Available at: <https://eurasianet.org/in-new-bidagainst-court-pashinyan-calls-for-referendum>. [Accessed 19th March 2020].

EURONEWS (2019). Nikol Pashinyan: Armenia will not be authoritarian. [online]. Available at: <https://www.euronews.com/2019/03/08/nikolpashinyan-armenia-will-not-be-authoritarian>. [Accessed 14th August 2019].

FACTOR (2019). The actions of sabotage against people's government mean actions of sabotage against people and the Republic of Armenia (In

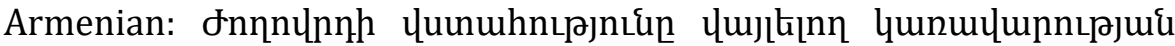

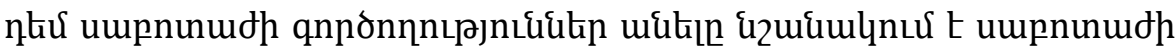

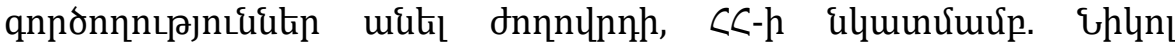
Фu2hijuiu). [online]. Available at: <https://factor.am/55233.html>. [Accessed 18th July 2019].

GEORGIA JOURNAL (2010). President of Georgia's address to European Parliament Members. [online]. Available at: <https://www. georgianjournal.ge/politics/1453-president-of-georgias-address-toeuropean-parliament-members-.html>. [Accessed 17th July 2019].

GHAPLANYAN, I. (2017). Post-Soviet Armenia: The New national elite and the new national narrative. Routledge, 2017.

GÖL, A. (2005). Imagining the Turkish nation through 'othering' Armenians. In: Nations and Nationalism. Vol. 11, No. 1, 2005, pp. 121-139.

GREENBERG, I. (2004). The Not-So-Velvet Revolution. [online]. Available at <https://www.nytimes.com/2004/05/30/magazine/the-not-so-velvetrevolution.html>. [Accessed 17th July 2019]. 
GRIGORYAN, A. (2019). Armenia's path to democratization by recursive mass protests. In: Caucasus Survey. Vol. 7, No. 2, 2019, pp. 157-175.

GRIGORYAN, A. (2019). Reforms in Armenia: the challenges ahead: The postrevolutionary momentum needs to be used. [online]. Available at: <https:// progressivepost.eu/debates/reforms-in-armenia-the-challengesahead $>$. [Accessed 13th July 2019].

JONES, S. F. (ed.). (2014). The making of modern Georgia, 1918-2012: the first Georgian republic and its successors. Routledge, 2014.

JUNG, H. (2019). The evolution of social constructivism in political science: past to present. In: SAGE Open. Vol. 9, No. 1, 2019, pp. 1-10.

KAKACHIA, K., LEBANIDZE, B., DUBOVYK, V. (2019). Defying marginality: explaining Ukraine's and Georgia's drive towards Europe. In: Journal of Contemporary European Studies. Vol. 27, No, 4, 2019, pp. 451-462.

KAKACHIA, K., MINESASHVILI, S. (2015). Identity politics: Exploring Georgian foreign policy behavior. In: Journal of Eurasian Studies. Vol. 6, No. 2, 2015, pp. 171-180.

KUCERA, J., MEJLUMYAN, A. (2019). Armenia: After Ex-president released, Premier opens conflict with judges and Karabakh leaders. [online]. Available at: <https://eurasianet.org/armenia-after-ex-presidentreleased-premier-opens-conflict-with-judges-and-karabakh-leaders $>$. [Accessed 15th July 2019].

LUCARELLI, S. (2008). European political identity, foreign policy and the Others' image. In: The Search for a European Identity: Values, Policies and Legitimacy of the European Union, 2008, pp. 23-42.

MARKAROV, A. (2018). Armenia's Foreign Policy Priorities. Are There Any Major Changes Following the Spring 2018 Political Transformation? In: Caucasus Analytical Digest. No. 104, 2018, pp. 3-7.

MINESASHVILI, S. (2016). Narrating identity: Belongingness and alterity in Georgia's foreign policy. In: KAKACHIA, K., \& MARKAROV, A. (ed.) Values and identity as sources of foreign policy in Armenia and Georgia. Universal, 2016, pp. 11-33.

NIKITIN, A. (2007). The End of the 'Post-Soviet Space': The Changing Geopolitical Orientations of the Newly Independent States. [online]. Available at: <https://www.chathamhouse.org/sites/default/files/ public/Research/Russia\%20and\%20Eurasia/bpnis0207.pdf >. [Accessed 14th June 2019].

ODDO, J. (2011). War legitimation discourse: Representing 'Us' and 'Them' in four US presidential addresses. In: Discourse \& Society. Vol. 22, No. 3, 2011, pp. 287-314. 
PASHINYAN (2018a). Prime Minister Nikol Pashinyan's congratulatory remarks on the 100th Anniversary of the Republic of Armenia and the May Battles. [online]. Available at: <https://www.primeminister.am/en/ statements-and-messages/item/2018/05/28/Prime-Minister-NikolPashinyans-address/>. [Accessed 17th July 2019].

PASHINYAN (2018b). Address by acting Prime Minister Nikol Pashinyan to National Assembly. [online]. Available at: <https://www.primeminister. am/en/statements-and-messages/item/2018/10/24/Nikol-PashinyanSpeech-National-Assembly/>. [Accessed 16th July 2019].

PASHINYAN (2018c). Prime Minister Nikol Pashinyan's speech at rally dedicated to 100 Days in Office. [online]. Available at: <https://www. primeminister.am/en/statements-and-messages/item/2018/08/17/ Nikol-Pashinyan-100-day-rally/>. [Accessed 18th July 2019].

PASHINYAN (2019a). Message by RA Prime Minister Nikol Pashinyan on March 1. [online]. Available at: <https://www.primeminister.am/ en/statements-and-messages/item/2019/03/01/Nikol-PashinyanMessage/>.

PASHINYAN (2019b). "100 Facts about New Armenia" - Introductory remarks by Prime Minister Nikol Pashinyan, delivered at the press conference. [online]. Available at: <https://www.primeminister.am/en/interviewsand-press-conferences/item/2019/05/08/Nikol-Pashinyan-PressConference/>. [Accessed 17th July 2019].

PASHINYAN, N. (2020). The people of Armenia shall decide on the Constitutional Court issue,- PM Nikol Pashinyan addresses the extraordinary session of the National Assembly. [online]. Available at <https://www.primeminister. am/en/statements-and-messages/item/2020/02/06/Nikol-PashinyanSpeech/>. [Accessed 19th March 2020].

PETERSSON, B. (2006). Stories about strangers: Swedish media constructions of socio-cultural risk. University Press of America, 2006.

REUTERS (2018). New Armenian PM tells Putin he wants closer ties with Russia. [online]. Available at: <https://www.reuters.com/article/usrussia-armenia-putin-pashinyan/new-armenian-pm-tellsputin-hewants-closer-ties-with-russia-idUSKCN1IF1A3>. [Accessed 14th July 2019].

RUGGIE, J. G. (1998). What makes the world hang together? Neoutilitarianism and the social constructivist challenge. In: International organization. Vol. 52, No. 4, 1998, pp. 855-885.

SAAKASHVILI (2005a). President Mikheil Saakashvili's annual report to Parliament. [online]. Available at <http://www.saakashviliarchive.info/ 
en/PressOffice/Documents/AnnualReports?p=4950\&i=1>. [Accessed 14th June 2019].

SAAKASHVILI (2005b). Georgian President addresses Nation ahead of Bush visit. [online]. Available at: <http://www.saakashviliarchive.info/en/ PressOffice/News/SpeechesAndStatements?p=2765\&i=1>. [Accessed 16th July 2019].

SAAKASHVILI (2005c). President Saakashvili addresses nation ahead of Rose Revolution anniversary. [online]. Available at: <http://www.saakashviliarchive.info/en/PressOffice/News/ SpeechesAndStatements? $\mathrm{p}=2711 \& \mathrm{i}=1>$. [Accessed 15th July 2019].

SAAKASHVILI (2006). Address by President Saakashvili at Independence day parade. [online]. Available at: <http://www.saakashviliarchive.info/en/ PressOffice/News/SpeechesAndStatements?p=2661\&i=1>. [Accessed 17th July 2019].

SAAKASHVILI (2007). Georgian President Mikheil Saakashvili delivers annual address to parliament. [online]. Available at: <http:// www.saakashviliarchive.info/en/Press Office/Documents / AnnualReports? $\mathrm{p}=4952 \& \mathrm{i}=1>$. [Accessed 8th July 2019].

SAAKASHVILI (2007b). Remarks by H.E. Mikheil Saakashvili at the 62nd Session of the United Nations. [online]. Available at: <http://www.saakashviliarchive.info/en/PressOffice/News/ SpeechesAndStatements? $\mathrm{p}=2372 \& \mathrm{i}=1>$. [Accessed 9th July 2019].

SAAKASHVILI (2007c). President Mikheil Saakashvili's address at the NATO Parliamentary Assembly's 65th Rose-Roth seminar in Tbilisi on 19 April. [online]. Available at: <http://www.saakashviliarchive.info/en/ PressOffice/News/SpeechesAndStatements? $\mathrm{p}=2392 \& \mathrm{i}=1>$. [Accessed 9th July 2019].

SAAKASHVILI (2007d). Georgian president praises winegrowers resolve, calls for unity amidst embargo. [online]. Available at: <http://www.saakashviliarchive.info/en/PressOffice/News/ SpeechesAndStatements? $\mathrm{p}=2368 \& \mathrm{i}=1>$. [Accessed 16th August 2019].

SAAKASHVILI (2007e). Georgian president addresses nation after unrest. [online]. Available at: <http://www.saakashviliarchive.info/en/ PressOffice/News/SpeechesAndStatements?p=2360\&i=1>. [Accessed 8th July 2019].

SAAKASHVILI (2008a). The President of Georgia made a statement before his departure to Bucharest. [online]. Available at: <http://www.saakashviliarchive.info/en/PressOffice/News/ SpeechesAndStatements? $\mathrm{p}=2345 \& \mathrm{i}=1>$. [Accessed 8th July 2019]. 
SAAKASHVILI (2008b). The President of Georgia Mikheil Saakashvili's annual speech presented in the Parliament of Georgia. [online]. Available at: $\quad$ http://www.saakashviliarchive.info/en/PressOffice/News/ SpeechesAndStatements? $\mathrm{p}=2304 \& \mathrm{i}=1>$. [Accessed 9th July 2019].

SAAKASHVILI (2008c). Press conference Georgia's President Mikheil Saakashvili and German Federal Chancellor Angela Merkel. [online]. Available at: <http://www.saakashviliarchive.info/en/PressOffice/ News/SpeechesAndStatements? $\mathrm{p}=2239 \& \mathrm{i}=1>$. [Accessed 9th July 2019].

SAAKASHVILI (2008d). The President of Georgia Mikheil Saakashvili's statement. [online]. Available at: <http://www.saakashviliarchive. info/en/PressOffice/News/SpeechesAndStatements? $\mathrm{p}=2312 \& \mathrm{i}=1>$. [Accessed 9th July 2019].

SAAKASHVILI (2008e). The President of Georgia Mikheil Saakashvili's address to the population of Georgia. [online]. Available at: <http://www.saakashviliarchive.info/en/PressOffice/News/ SpeechesAndStatements? $\mathrm{p}=2310 \& \mathrm{i}=1>$. [Accessed 17th July 2019].

SAAKASHVILI (2010a). Mikheil Saakashvili: Extraordinary achievements are needed to survive. [online]. Available at: $<$ http://www.saakashviliarchive. info/en/PressOffice/News/Interviews?p=5542\&i=2>. [Accessed 16th July 2019].

SAAKASHVILI(2010b).ThePresidentofGeorgiamadea speechatParisInstitute ofPoliticalScience. [online]. Available at:<http://www.saakashviliarchive. info/en/PressOffice/News/SpeechesAndStatements? $\mathrm{p}=5262 \& \mathrm{i}=1>$. [Accessed 14th July 2019].

SAAKASHVILI (2010c). Parliamentary majority session was held in Batumi. [online]. Available at: <http://www.saakashviliarchive.info/en/ PressOffice/News/SpeechesAndStatements? $\mathrm{p}=5275 \& \mathrm{i}=1>$. [Accessed 14th July 2019].

SAAKASHVILI (2010d). The meeting of the president of Georgia with the majority members of Georgia's Supreme legislative body in Anaklia. [online]. Available at: <http://www.saakashviliarchive.info/print. aspx?t=1\&i=5409>. [Accessed 15th July 2019].

SAAKASHVILI (2011a). The joint briefing of the Presidents of Georgia and Poland. [online]. Available at: <http://www.saakashviliarchive.info/en/PressOffice/ News/SpeechesAndStatements?p=6715\&i=1>. [Accessed 15th July 2019].

SAAKASHVILI (2011b). The President of Georgia has given a speech at the opening ceremony of the Ronald Reagan statue. [online]. Available at: $\quad$ <http://www.saakashviliarchive.info/en/PressOffice/News/ SpeechesAndStatements? $\mathrm{p}=7143 \& \mathrm{i}=1>$. [Accessed 15th July 2019]. 
SAAKASHVILI (2012a). The President of Georgia opened the first session of the 8th Parliament of Georgia. [online]. Available at: <http://www.saakashviliarchive.info/en/PressOffice/News / SpeechesAndStatements? $\mathrm{p}=7937 \& \mathrm{i}=1>$. [Accessed 16th July 2019].

SAAKASHVILI (2012b). The day after: President Mikheil Saakashvili on postrevolutionary societies \& what comes after the Arab Spring. [online]. Available at: <http://www.saakashviliarchive.info/en/PressOffice/ News/SpeechesAndStatements?p=7319\&i=1>. [Accessed 14th July 2019].

SCHIFFRIN, D. (1996). Narrative as self-portrait: Sociolinguistic constructions of identity. In: Language in Society. Vol. 25, No. 2, 1996, pp. 167-203.

STATE.GOV (2014). Department of State: 2014 Investment climate statement. [online]. Available at: <https://2009-2017.state.gov/documents/ organization/229020.pdf>. [Accessed 17th July 2019].

STRÅTH, B. (2008). Belonging and European identity. In: Identity, Belonging and Migration. 17, 2008, pp. 21-37.

TASS (2018). Military partnership with Russia remains major factor for Armenia's security - Pashinyan. [online]. Available at: <https://tass. com/world/1003273 >. [Accessed 14th August 2019].

TERZYAN, A. (2018). Identity Conflicts? The Sense of 'victimhood' and the enemy images of Turkey and Azerbaijan in the foreign policy discourse of Armenia. In: Slovak Journal of Political Sciences. Vol. 18, No. 2, 2018, pp. 155-175.

TERZYAN, A. (2019a). The Aftermath of the "Velvet Revolution": Armenia between domestic change and foreign policy continuity. In: Eastern European Journal for Regional Studies (EEJRS). Vol. 5, No.2, 2019, pp. 2443.

TERZYAN, A. (2019b). Russian policy, Russian Armenians and Armenia: ethnic minority or political leverage? In: Centre for European Studies (CES) Working Papers. Vol. 11, No. 2, 2019, pp. 124-142.

TERZYAN, A. (2019c). Bringing Armenia closer to Europe: challenges to the EU-Armenia Comprehensive and Enhanced Partnership Agreement implementation. In: Romanian Journal of European Affairs. Vol. 19, No, 2, 2019, pp. 97-110.

THE GUARDIAN (2009). Georgian president Mikheil Saakashvili blamed for starting Russian war. [online]. Available at: <https://www.theguardian. com/world/2009/sep/30/georgia-attacks-unjustifiable-eu>. [Accessed 15th July 2019]. 
TIEANU, A. (2013). From alterity to identity: A central European view of Europe at the end of the twentieth century. In: Journal of the Lucas Graduate Conference, 2013, pp 20-31. [online]. Available at: <https:// openaccess.leidenuniv.nl/bitstream/handle/1887/20533/JLGC1-7\%20Tieanu.pdf?sequence=1>. [Accessed 15th March 2020].

TREATY ON THE EURASIAN ECONOMIC UNION (2014). [online]. Available at: <https://www.wto.org/english/thewto_e/acc_e/kaz_e/WTACCKAZ85_ LEG_1.pdf>. [Accessed 15th July 2019].

TUCKER, J. A. (2007). Enough! Electoral fraud, collective action problems, and post-communist colored revolutions. In: Perspectives on Politics. Vol. 5, No. 3, 2007, pp. 535-551. 